\title{
Interpretation of UNCLOS Article 76 and the Negative Recommendation of the Commission on the Limits of the Continental Shelf on Ascension Island: Is the United Kingdom Stuck with It?
}

\author{
Andrew Serdy*
}

\begin{abstract}
The 2010 recommendation to the United Kingdom is to date the only one the Commission on the Limits of the Continental Shelf has made to any submitting State for the outer limit of the continental shelf not to run beyond 200 nautical miles from the baseline. On its face the rationale for the recommendation appears defensible since the predominantly geomorphological approach to UNCLOS Article 76 on which it depends is one that it was open to the Commission to take, even if other interpretations are possible. The UK's criticism of the Commission for thereby exceeding its mandate is groundless, as Article 76 forces that role on it; the disagreement is about application rather than interpretation. But the UK has also hinted at flaws in the process by which the recommendation was reached, quoting from the written interactions between its delegation and the subcommission that examined its submission. As the UK has limited options if it still believes itself entitled to a continental shelf beyond 200 nautical miles around Ascension Island, coy hints of procedural irregularity potentially undermining the legitimacy of the negative recommendation are unlikely to be enough to persuade
\end{abstract}

Reader in Public International Law, University of Southampton. This is an expanded version of a paper entitled 'Interpretation of UNCLOS Article 76 and the Commission on the Limits of the Continental Shelf Recommendation on Ascension Island: Should the United Kingdom Grin and Bear It?' delivered in October 2012 at the 7th Conference of the (International Hydrographic Organisation and International Association of Geodesy) Advisory Board on the Law of the Sea, Monaco. The author thanks the reviewers for their suggestions which have led to improvements in the text, and Robert Veal for research assistance associated with one of these.

Copyright (c) the Author(s).

This work is licensed under a Creative Commons Attribution-NonCommercial-NoDerivs 3.0 License. 
other States not to challenge its assertions of sovereign rights despite it. This might require preparedness to release the full record of its correspondence with the Commission to show that its grievance is soundly based, or turning to the States Parties for a collective view on the matter.

\section{Keywords}

Commission on the Limits of the Continental Shelf, Law of the Sea, UNCLOS

Article 76, continental shelf

\section{Introduction}

The 2010 recommendation by the Commission on the Limits of the Continental Shelf (CLCS or Commission) to the United Kingdom in respect of Ascension Island ${ }^{1}$ is the only one the Commission has made to date for the outer limit of the submitting state's continental shelf not to run beyond 200 nautical miles (nm) from the baseline. On its face the rationale for the recommendation appears defensible, since the predominantly geomorphological approach to Article 76 of the United Nations Convention on the Law of the $\mathrm{Sea}^{2}$ (UNCLOS) on which it depends is one that was open to the Commission to take. The UK, however, has criticised the Commission for exceeding its mandate by purporting to interpret Article 76. It has also hinted at flaws in the process by which the recommendation was reached, quoting from the written interactions between its delegation and the subcommission that examined its submission. ${ }^{3}$ This article investigates whether

\footnotetext{
1 Summary of Recommendations of the Commission on the Limits of the Continental Shelf in regard to the Submission made by the United Kingdom of Great Britain and Northern Ireland in respect of Ascension Island on 9 May 2008, 15 April 2010, <www.un.org/depts/los/clcs_new/subm issions_files/gbr08/gbr_asc_isl_rec_summ.pdf> [accessed 5 April 2013] (Ascension Island Recommendations).

2 United Nations Convention on the Law of the Sea, 10 December 1982, 1833 UNTS 3.

3 Paper Summarising the Presentation by the United Kingdom of Great Britain and Northern Ireland to the Commission on the Limits of the Continental Shelf on Points of Legal Interpretation, 12 April 2010, attached to Note No 08/11, 11 January 2011, addressed to the Secretary-General of the United Nations by the Permanent Mission of the United Kingdom of Great Britain and Northern Ireland (UK Paper), <http://www.un.org/depts/los/clcs_new/sub missions_files/gbr08/gbr_nv_11jan2011.pdf> [accessed 8 April 2013]. The detailed examination of submissions is delegated to subcommissions, whose draft recommendations are transmitted to the full Commission where a two-thirds majority is required to adopt them: Annex II to UNCLOS Annex II, Arts 5 and 6(1) and (2).
} 
or not the criticism is sound, and the limited options the UK has if it still believes itself entitled to a continental shelf beyond $200 \mathrm{~nm}$ around Ascension Island. It begins by setting out the content of the relevant provisions of UNCLOS, and then examines more closely the nature of the disagreement between the UK and the Commission. Attention then moves to whether there are any procedural shortcomings in the way the Commission arrived at its recommendation, and the obstacles, including a recent judgment of the International Tribunal for the Law of the Sea (ITLOS), in the way of the UK turning these to its advantage in order to obtain a better outcome.

The arguments put forward below are necessarily rather tentative because much of them involves reading between the lines of a document published on the Commission's website in January 2011 at the UK's request, ${ }^{4}$ attached to a diplomatic note sent to the UN Secretary-General. Prompted by the UK's disappointment at the recommendation denying that Ascension Island met the conditions to generate any continental shelf beyond $200 \mathrm{~nm},{ }^{5}$ the document is a summary of the UK's presentation to the full Commission on 'points of legal interpretation'. This was presented to the Commission during its consideration of the subcommission's draft recommendations, and shortly before it adopted its own recommendations. ${ }^{6}$ It quotes from a number of documents of the subcommission leading up to and including its draft recommendations to the full Commission.

Since interactions between the CLCS and submitting states are not usually made public, ${ }^{7}$ the situation is a prime illustration of what a former Legal Ad-

\footnotetext{
${ }^{4}$ UK Paper, above $\mathrm{n} 3$.

${ }^{5}$ Ascension Island Recommendations, above n 1, 15 (paras 53-54).

${ }^{6}$ Rules of Procedure of the Commission on the Limits of the Continental Shelf, UN Doc CLCS/40/Rev.1, 17 April 2008, Annex III (Modus operandi for the consideration of a submission made to the Commission on the Limits of the Continental Shelf), rule 15 (1bis) of which lays down that the submitting state should be given such an opportunity.

${ }^{7}$ An exception is the full recommendations in reaction to Ireland's partial submission, to which the questions from the subcommission and the responses of the Irish delegation are (separately) annexed: Recommendations of the Commission on the Limits of the Continental Shelf in regard to the Partial Submission made by Ireland on the Proposed Outer Limit of its Continental Shelf beyond 200 Nautical Miles in the Area Abutting the Porcupine Abyssal Plain, 25 May 2005, <http://www.un.org/depts/los/clcs_new/submissions_files/irl05/irl_rec.pdf> [accessed 3 January 2013]. Some states have been prepared to release the full recommendations received from the CLCS, rather than just their executive summary, such as New Zealand: Recommendations of the Commission on the Limits of the Continental Shelf (CLCS) in regard to the Submission made by New Zealand, 19 April 2006, <http://www.mfat.govt.nz/down loads/global-issues/cont-shelf-recommendations.pdf> [accessed 3 January 2013]. An inter-
} 
viser in the Foreign and Commonwealth Office has described as the invisible conduct' of states forming part of the 'secret life' of international law, which can nonetheless, from its visible effects, be 'deduced and identified.' ${ }^{8}$ There is accordingly some risk of factual error vitiating some or all of the conclusions reached below by inferring from the limited public record what might actually have happened, and the author would welcome either confirmation or corrections from any reader with first-hand knowledge of the interactions concerned. ${ }^{9}$

\section{Background}

Under Article 76, paragraph 1, of UNCLOS, the outer limit of a state's continental shelf is defined by reference to 'the outer edge of the continental margin', or alternatively is set at '200 nautical miles from the baselines from which the breadth of the territorial sea is measured where the outer edge of the continental margin does not extend up to that distance'.

The term 'continental margin' is defined in paragraph 3 of the same Article as 'compris[ing] the submerged prolongation of the land mass of the coastal state, and consists of the sea-bed and subsoil of the shelf, the slope and the rise'. It adds by way of clarification that this 'does not include the deep ocean floor with its oceanic ridges or the subsoil thereof'.

Contrary to the apparent implication of paragraph 1, however, the outer limit of the continental shelf does not in fact coincide exactly with the edge of the continental margin when this lies over $200 \mathrm{~nm}$ from the baseline. This is made clear in paragraph 2 of Article 76, which points to a more precise formula

mediate case is that of Australia: Recommendations of the Commission on the Limits of the Continental Shelf (CLCS) in regard to the Submission made by Australia (Recommendations to Australia), 15 November 2004, <http://www.un.org/depts/los/clcs_new/submissions_fi les/aus04/Aus_Recommendations_FINAL.pdf> [accessed 2 January 2013], where the existence of Annex IV, 'Communications between the Subcommission and the Delegation of Australia', is disclosed, but this annex is not posted on the website 'for technical reasons': <http://www.un.org/depts/los/clcs_new/submissions_fi les/submission_aus.htm> [accessed 2 January 2013]; a reasonably informative list of the documents generated has however been posted as part of Annex I: <http://www.un.org/depts/los/clcs_new/submissions_files/aus04/list-ofmaterial-sessions.pdf $>$ [accessed 2 January 2013].

8 D Bethlehem, 'The Secret Life of International Law' (2012) 1 CJICL 23, 29-31 and 36.

9 The author made the same plea when presenting this paper on the occasion mentioned above $\mathrm{n}^{*}$, but neither confirmation nor an alternative version of events was proffered by any of the several members of the audience who had such knowledge; no firm conclusion either way should be drawn from their silence. 
elsewhere in the same Article: the shelf 'shall not extend beyond the limits provided for in paragraphs 4 to 6. Paragraphs 5 and 6 are constraining provisions of only tangential relevance to the present discussion, ${ }^{10}$ but subparagraph 4(a) specifies that the coastal state has a choice between placing the outer limit along either:

(i) A line delineated in accordance with paragraph 7 by reference to the outermost fixed points at each of which the thickness of sedimentary rocks is at least 1 per cent of the shortest distance from such point to the foot of the continental slope; or

(ii) A line delineated in accordance with paragraph 7 by reference to fixed points not more than 60 nautical miles from the foot of the continental slope.

Common to these alternatives are the concepts of 'the foot of the continental slope' as the starting point, which subparagraph 4(b) defines '[i]n the absence of evidence to the contrary [...] as the point of maximum change in the gradient at its base'. A cross-reference to paragraph 7 of Article 76 gives further detail on the construction of the outer limit line by instructing the coastal state to delineate the outer limits of its continental shelf beyond $200 \mathrm{~nm}$ from its baseline "by straight lines not exceeding 60 nautical miles in length, connecting fixed points, defined by co-ordinates of latitude and longitude'.

Article 76 of UNCLOS deals not just with the substance of the location of the outer limit of the continental shelf, but also with the process for its determination. No special procedure is required where the application of the above rules in paragraphs 4 and 7 would produce a continental shelf whose outer limit is nowhere more than $200 \mathrm{~nm}$ from the baseline, as this is displaced by the automatic entitlement in paragraph 1 to a continental shelf of $200 \mathrm{~nm}$. By contrast, where the coastal state believes the application of the rules in paragraphs 4 and 7 would lead to a continental shelf extending more than $200 \mathrm{~nm}$ from its baselines, paragraph 8 of Article 76 allows it to make a submission to a specially created body, the CLCS, which is directed to 'make recommendations to coastal states on matters related to the establishment of the outer limits of their continental shelf'. It goes on to provide that limits 'established by a coastal state on the basis of these recommendations shall be final and binding.'

Within the part of this paragraph not quoted is a further cross-reference, this time to Annex II, which contains a number of provisions on the establishment

${ }^{10}$ See however below n 36 and accompanying text. 
and operation of the Commission. The most significant provisions in Annex II for our purposes are paragraph 1 of Article 2, which provides that the CLCS shall consist of 21 members elected by the states parties to UNCLOS serving in their personal capacities, who must be 'experts in the field of geology, geophysics or hydrography', and subparagraph 1(a) of Article 3, which lays down the primary function of the CLCS, namely to consider the submissions made to it by coastal states and make the recommendations contemplated by Article 76, paragraph 8, 'in accordance with article 76'.

\section{The disagreement: interpretation or application?}

The CLCS gave extensive reasons for its negative 2010 recommendation to the UK. ${ }^{11}$ At the risk of oversimplifying them, these are that Ascension Island does not fulfil the conditions for a continental shelf beyond $200 \mathrm{~nm}$ because it lies not directly on the crest of the Mid-Atlantic Ridge but off to one side on its western flank. Accordingly, one would have to take an artificially distorted view of where its foot of slope is under paragraph 4 of Article 76 of UNCLOS to conclude that the underwater extension of the landmass, its natural prolongation in terms of paragraphs 1 and 3, encompasses not just the island's surrounds but can be followed onto the main axis of the ridge. A contrast can be drawn with Macquarie Island, located on the main axis of a ridge of oceanic crust, which the Commission's 2008 recommendations to Australia confirmed as having such an entitlement. ${ }^{12}$ There is an obvious parallel with Iceland, a much larger island on the Mid-Atlantic Ridge, whose submission has yet to be considered by the Commission. ${ }^{13}$

Was the Commission right or wrong to reject the thrust of the UK's submission? From a legal perspective, this is too simple a question to be asking; it needs to be split into its two component parts, namely is the Commission's recommendation vitiated, on the one hand, by any unsoundness of its scientific reasoning or, on the other hand, by some other kind of error that might have legal effects? Since the situation is legally comparatively uninteresting if the answer to

\footnotetext{
${ }^{11}$ Ascension Island Recommendations, above n 1, 8-15 (paras 28-52).

${ }^{12}$ Recommendations to Australia, above n 7, 34 (para 115).

${ }^{13}$ For the executive summary of the Icelandic submission see <http://www.un.org/depts/1 os/clcs_new/submissions_files/isl27_09/isl2009executivesummary.pdf> [accessed 2 January 2013].
} 
both parts is negative, it is more illuminating, if admittedly somewhat unfair to the Commission, to dwell on what the consequences are if it is wrong, which may differ depending on why it is wrong.

The purpose of paragraph 8 of Article 76 in making the Commission's recommendations 'final and binding' is to achieve legal certainty. Recalling Article 2, paragraph 1 of Annex II above, this is achieved by barring other states from calling into question its determinations regarding the conformity of the outer limit with the rules of paragraphs 4 to 7 because of errors needing expertise in one of the three fields of geophysics, geology or hydrography to detect. By contrast, given the ambiguity in the passage of the judgment of ITLOS in the Bay of Bengal case ${ }^{14}$ as to whether this condition is purely procedural or also substantive, errors of law in the recommendations (or, more likely, in the supporting reasoning), for example the imposition by the CLCS of restrictions or conditions unfounded in Article 76, or errors that anyone can spot without being an expert in any of the three named fields, such as errors of logic or arithmetic, do not, or should not, enjoy the same protection.

For a time, the Commission's recommendation on Ascension Island and its supporting reasoning were all there was on the public record, and while this remained so, it appeared, at least on the face of it, to have avoided any error of these latter types. The recommendation appeared defensible since it relies on a predominantly geomorphological approach to Article 76 of UNCLOS which is certainly consonant with the text, even if on matters of detail other interpretations are possible. In this sense, the Commission can be right even when wrong-the proper legal question then is not whether its interpretation is incontrovertibly correct, but rather whether its view is one that was open to the Commission to take, and if the answer is yes, as appears to be the case, that should conclude the matter.

That potentially changed, however, when the UK Paper was posted to the Commission's website. The UK Paper argues that the Commission did after all fall into legal error. It states that the CLCS has no authority to interpret Article 76 of UNCLOS:

[The Commission] does not have a plenary right to interpret the Convention, which is a task for lawyers. In this connection, we note

\footnotetext{
${ }^{14}$ Delimitation of the Maritime Boundary between Bangladesh and Myanmar in the Bay of Bengal (Bangladesh v Myanmar), ITLOS Case No 16 Judgment, (14 March 2012) para 407: 'It is only after the limits are established by the coastal state on the basis of the recommendations of the Commission that these limits achieve their final and binding status'.
} 
that the Commission's Rules of Procedure allow it to seek outside specialist advice. Since there are clear differences in legal interpretation between the United Kingdom and the Subcommission, we suggest that the Commission should consider seeking specialised outside legal advice on these questions. ${ }^{15}$

In particular, the paper lists three matters on which the UK takes issue with the subcommission: interpretation of the terms 'deep ocean floor' and 'natural prolongation' and the preference for morphological over geological arguments. ${ }^{16}$ It cites an International Law Association (ILA) study which begins by accepting that the Commission has the power to interpret as well as apply Article $76,{ }^{17}$ but then all but qualifies this out of existence by saying that, since interpretation of treaties is primarily a matter for the states party to them, it should accept any reasonable interpretation offered by the submitting state. ${ }^{18}$

While there is something to be said for this attitude, it is wholly unrealistic to expect a body charged with the task of applying a legal text to be able to avoid altogether having to interpret it, a role that could be said to be forced on it by the circumstances. So too in UNCLOS the Commission was created specifically as a technical body to apply Article 76, and it is necessary to ensure a degree of consistency in how it does this, if it is to fulfil the aim of reassuring other states that broad-margin states are not extending their jurisdiction over areas to which the rules do not entitle them. The only practical solution is to centralise in the Commission the function of providing interpretations on technical or scientific questions such as where the base of the slope is, or what is acceptable evidence for locating the foot of slope. ${ }^{19}$ Nor is it clear how the UK's suggestion of obtaining external legal advice would have solved the problem. The Commission would not be bound by that advice but would still have to decide whether to accept and act on it; if it did so, the external adviser's interpretation in effect would become the Commission's and there is no guarantee that it would be on all fours with that of the submitting state. This is not to say that the Commission

\footnotetext{
${ }^{15}$ UK Paper, above n 3, 7 (para 32).

${ }^{16}$ Ibid, 2 (para 6).

${ }^{17}$ Second Report of the ILA's now disbanded Committee on Legal Issues of the Outer Continental Shelf, reprinted in ILA, Report of the Seventy-Second Conference (Toronto 2006) (2006) 215, 228 (Conclusion 9) and 229 (accompanying Explanatory Note).

${ }^{18} \mathrm{Ibid}, 228$ (Conclusion 9) and 229-231 (accompanying Explanatory Note).

${ }^{19}$ Accord generally B Kunoy, 'Legal Problems Relating to Differences Arising between Recommendations of the CLCS and the Submission of a Particular State', in C R Symmons (ed), Selected Contemporary Issues in the Law of the Sea (2011) 305, 311-3.
} 
should have carte blanche when it comes to interpretation-there is much to criticise about its tendency, admittedly more pronounced on procedural than on substantive issues (though by no means confined to the former), to limit the rights of submitting states and impose obligations on them not justified by the text of Article $76,{ }^{20}$ but that is not the problem here. As long as the Commission avoids falling into legal, logical or arithmetical error in performing its technical task, we should afford it some latitude, as occurred in a fairly closely analogous recent arbitration involving a challenge to the findings of experts in history and geography on which the course of a boundary depended, in which the tribunal was prepared to look into the question of whether the experts had exceeded their mandate as set out in the instrument under which they were appointed. ${ }^{21}$ The clue to the way out of this dilemma lies in the use of the plural in the latter part of the ILA's statement, together with the modifying adverb 'primarily'. It may be conceded that a collective interpretation of a treaty provision by the parties to the treaty is definitive, ${ }^{22}$ but it would be counterproductive to the aim of obtaining legal certainty in the form of a universally recognised outer limit for the continental shelf if, as the UK advocates, ${ }^{23}$ individual submitting states could expect to maximise their continental shelves by putting forward differing

\footnotetext{
${ }^{20}$ See A Serdy, "The Commission on the Limits of the Continental Shelf and its Disturbing Propensity to Legislate' (2011) 26 International Journal of Marine and Coastal Law 355.

${ }^{21}$ Abyei Dispute (Government of Sudan v Sudan People's Liberation Movement) (2009) 144 ILR 348, 506 (para 406). The standard applied by the arbitral tribunal was whether the experts' findings were reasonable rather than whether they were correct, because the experts and the tribunal were 'each programmed to assess the facts using quite different methodologies (i.e. the methodology of science vis-à-vis the methodology of law)'. This factor also ruled out the direct application of the considerable corpus of jurisprudence of ad hoc committees on annulment of arbitral awards under Article 52(1) of the Convention on the Settlement of Investment Disputes between States and Nationals of Other States, 18 March 1965, 575 UNTS 159, to the effect that not just the factual but (except in extreme cases) also the legal decisions of the original decision-making body should remain undisturbed, since the decisions sought to be annulled were those of 'an adjudicatory body strictu [sic] sensu' (505, paras 404-5), a description fitting neither the Abyei Boundaries Commission experts nor the CLCS. An example of how a logical error can constitute an annullable excès de pouvoir is the tribunal's quashing of the part of the boundary determined by the experts due to the absurdity of their having drawn conclusions from evidence that they themselves had previously considered inconclusive (595-6; paras 687-8). On the paucity of meaningful accountability mechanisms for the CLCS's operations see also A Cavnar, 'Accountability and the Commission on the Limits of the Continental Shelf: Deciding Who Owns the Ocean Floor' (2009) 42 Cornell International Law Journal 387, 412-24.

${ }^{22}$ See the Vienna Convention on the Law of Treaties, 23 May 1969, 1155 UNTS 331, Art 31(3)(a) (VCLT).

${ }^{23}$ The effect, if not the intention, of the ILA in lapsing into the singular is to endorse this.
} 
interpretations, each favouring its own case but mutually inconsistent. We return to this matter below.

Though portrayed as a question of interpretation, where the Commission's role is indeed circumscribed, the UK's grievance seems to this author to be much more about the application of Article 76. The nub of the UK's objections to the draft recommendations from the subcommission is that, despite accepting the principle of crustal neutrality by which land that is oceanic crust is no less entitled to a continental shelf than land that is continental crust, ${ }^{24}$ the subcommission manifestly failed to apply it. Going by the UK Paper's account, it seems that the subcommission thought that mid-oceanic ridges in general, and the Mid-Atlantic Ridge in particular, form part of the deep ocean floor within the meaning of paragraph 3 of Article 76, and therefore are not part of the continental shelf, so that islands atop them such as Ascension Island cannot have a continental shelf beyond $200 \mathrm{~nm}$ from the baseline. ${ }^{25}$ Had the subcommission actually taken this view, it would have been an astonishing misconception as to a fundamental feature of Article 76-the assumption that any seabed that is part of the legal continental margin cannot be part of the deep ocean floor and vice versa, as though the two terms were mutually exclusive $-{ }^{26}$ and one can agree with the UK that:

Therefore, some ridges, or parts of ridges, belong to the deep ocean floor; some [...] do not. Ridges may also change their juridical status from margin to deep ocean floor as they move away from a land mass [...] there must be parts of mid oceanic ridges that are part of the deep ocean floor in both the scientific and legal sense. However, the Subcommission appears to have made the

\footnotetext{
${ }^{24}$ UK Paper, above n 3, 2 (para 7 and dependent footnote).

${ }^{25}$ Ibid, $2-3$ (paras 10-1).

${ }^{26}$ There is some evidence that the Commission has in fact made this grave error in the past: it probably underlies the recommendations to New Zealand in 2008 which resulted in excision of an area from its continental shelf to leave a hole in the middle, criticised in Serdy, above n 20, $376-7$. This elevates para 3 over paras $4-7$ which are where the rules the Commission is supposed to apply are found. It amounts to saying that the provisions cannot have been applied correctly if there is any area of deep ocean floor landward of the outer limit, because such an area cannot form part of a state's continental shelf. Para 3 is part of the general description of the continental shelf, intended to define what the legal continental shelf is-in essence, an approximation of the continental margin -in part by highlighting what it is not, i.e. what lies beyond: the deep ocean floor. That is obviously true in general terms but it should be given no more significance than that; the particularities of where the outer limit line runs are governed by paras $4-7$, and occasionally their simplifying effect is to leave areas of continental margin on the seaward side and deep ocean floor on the landward side.
} 
unwarranted assumption that all mid oceanic ridges are deep ocean floor. The United Kingdom does not accept this. Rather, one must first test whether the requirements of Article 76 for establishing continental margin have been met. If the assumption that the area around Ascension is deep ocean floor is removed, then we consider that the test of appurtenance can be demonstrated, in accordance with normal principles [...]. ${ }^{27}$

Far from supporting this charge, though, the relevant footnote in the UK Paper indicates otherwise: the subcommission came to its conclusion based on where it thought the foot of slope was, a question that would have been irrelevant if it believed Ascension Island was limited a priori to $200 \mathrm{~nm}$ of continental shelf. Thus, while the subcommission may well at one point have made the mistake attributed to it by the UK, it did not ultimately rest its reasoning on that mistake. It may be conceded that mid-ocean ridges, for states without land territory on them, do indeed form part of the deep ocean floor. In line with the principle that the land dominates the sea, ${ }^{28}$ however, or as the UK Paper puts it, that UNCLOS Article 77 requires a land-based approach, ${ }^{29}$ the underwater part of such a ridge is clearly capable of being the natural prolongation of an island on the ridge. The recommendations to Australia in respect of Macquarie Ridge confirm this. ${ }^{30}$

The UK Paper next turns to a discussion of the application of the test of appurtenance to Ascension Island once the faulty assumption is removed, ${ }^{31}$ which eventually resolves itself into a complaint about the subcommission's 'strong preference for relying on morphological over geological criteria', occasionally to the complete exclusion of the latter. ${ }^{32}$ Without a complete record we cannot judge whether this is so, but the preference for geomorphology over geology is built into Article 76 itself, in which geomorphology is predominant ${ }^{33}$ except in three instances. These are: (1) the admissibility of 'evidence to the contrary' to displace

${ }^{27}$ UK Paper, above n 3, 5 (paras 19-20).

${ }^{28}$ See North Sea Continental Shelf Cases (Federal Republic of Germany/Denmark; Federal Republic of Germany/Netherlands), ICJ Reports 1969 p 3, 51 (para 96).

${ }^{29}$ UK Paper, above n 3, 4 (para 16 and dependent footnote).

${ }^{30}$ Recommendations to Australia, above n 7, 20 (para 71); note, however, the anomalous reference to a 'continent'.

${ }^{31}$ UK Paper, above n 3, 5 (paras 21-5).

32 Ibid, 6 (para 26).

33 This renders superficially anomalous, as a reviewer has pointed out, the omission of geomorphology (defined in P M B Walker (ed), Larousse Dictionary of Science and Technology (1995) 475 as the 'study of landforms and their relationship to the underlying geological structure') from the requisite specialisations of CLCS members in UNCLOS Annex II, Article 2(1), but is explicable 
the point of maximum change in gradient as the location of the foot of slope; ${ }^{34}$ (2) the thickness of sedimentary rocks beyond the foot of slope as one of the bases for the continental shelf to extend beyond $200 \mathrm{~nm}$ from the baseline; ${ }^{35}$ and (3) the identification of which submarine elevations are 'natural components of the continental margin' in order to avoid the 350-nm line exceptionally becoming the automatic constraint of the extent of the shelf on submarine ridges to the exclusion of the line $100 \mathrm{~nm}$ beyond the 2500 -metre isobath where the latter is more advantageous to submitting states. ${ }^{36}$

The UK Paper's discussion on the test of appurtenance is not easy to follow, but that is not intended as a criticism, for the test as set out in the Commission's Scientific and Technical Guidelines is itself more than a little elusive. At least part of it appears to be an acknowledgment that the establishment of natural prolongation might be viewed as a matter separate from and anterior to the identification of the outer edge of the continental margin:

by the fact that it is a 'branch of geology', which would make its separate listing tautologous: W D Thornbury, Principles of Geomorphology (1954) 1.

${ }^{34}$ UNCLOS Art 76(4)(b).

${ }^{35}$ UNCLOS Art 76(4)(a)(i).

${ }^{36}$ UNCLOS Art 76(5) and (6) Ironically, the UK itself makes an error very similar to that with which it now takes issue in conceding unnecessarily that the $350 \mathrm{~nm}$ cut-off applies on the Mid-Atlantic Ridge to the exclusion of the more generous depth constraint: see the UK's view that it is a 'submarine ridge' to which para 6 applies in Ascension Island Recommendations, above n 1, 9 (para 32). As the etymology of the adjective suggests, a 'submarine' ridge is one that is under the sea-but that is true of all ridges potentially forming part of a state's continental shelf. Hence, in accordance with the rule of effectiveness in treaty interpretation, by which some meaning must be given to each word, the result cannot be the same as if 'submarine' were simply omitted. To avoid this, it is suggested that a 'submarine ridge' should be regarded as one whose relevant parts, for the state concerned, are wholly underwater. A ridge with an island on it is, at least from the point of view of the state whose island it is, not wholly or even mainly under the sea (though it would be for other states whose continental shelves generated by other land territory might otherwise extend onto that ridge). Though the UK's self-denying stance is consonant with the apparent intent of the drafters of UNCLOS, under the rules of treaty interpretation in VCLT Arts 31 and 32, where the 'ordinary meaning to be given to the terms of the treaty in their context and in the light of its object and purpose' leads to a result that is not 'manifestly absurd or unreasonable', the preparatory work can serve only to confirm that meaning, not contradict it. Using the 'ordinary meaning' of 'submarine', it is neither absurd nor unreasonable for a ridge to be taken as not submarine from the perspective of a state with an island atop it, so that the island's continental shelf in fact extends as far as the ordinary rules of paras 4-5 can carry it. Iceland's 2009 submission, above n 13, implicitly relies on this preferable view. For the CLCS view on para 6 see H Brekke and P Symonds, 'Submarine Ridges and Elevations of Article 76 in Light of Published Summaries of Recommendations of the Commission on the Limits of the Continental Shelf' (2011) 42 Ocean Development \& International Law 294. 
2.2.2 The Commission defines the term of appurtenance as the process by means of which [paragraph $4(\mathrm{a})$ ] is examined. The test of appurtenance is designed to determine the legal entitlement of a coastal State to delineate the outer limits of the continental shelf throughout the natural prolongation of its land territory to the outer edge of the continental margin, or to a distance of 200 nautical miles from the baselines [...]

2.2.3 If a State is able to demonstrate to the Commission that the natural prolongation of its submerged land territory to the outer edge of its continental margin extends beyond the 200-nautical-mile distance criterion, the outer limit of its continental shelf can be delineated by means of the application of the complex set of rules described in paragraphs 4 to $10 .^{37}$

This is confusingly expressed, as under the immediately preceding paragraph 2.2.1, implementation of the delineation of the outer limit must be preceded by 'positive proof' of the entitlement. While paragraph 2.2.2 does not actually contradict this, paragraph 2.2.3 seems to be suggesting instead that both matters fall within paragraph 4 rather than the proof being governed by paragraphs 1 or 3 . This would be consistent with the CLCS's attempt a little further on to 'formulate' the test, which appears to reduce it to a restatement of paragraph 4 alone of Article 76:

2.2.8 The formulation of the test of appurtenance can be described as follows:

If either the line delineated at a distance of 60 nautical miles from the foot of the continental slope, or the line delineated at a distance where the thickness of sedimentary rocks is at least 1 per cent of the shortest distance from such point to the foot of slope, or both, extend beyond 200 nautical miles from the baselines from which the breadth of the territorial sea is measured, then a coastal State is entitled to delineate the outer limits of the continental shelf as prescribed by the provisions contained in article 76, paragraphs 4 to $10 .^{38}$

\footnotetext{
${ }^{37}$ Scientific and Technical Guidelines of the Commission on the Limits of the Continental Shelf, UN Doc CLCS/11, 13 May 1999, 12.

${ }^{38}$ Ibid, 13.
} 
Yet if the test of appurtenance is simply a different way of saying what is already in paragraph 4, as distinct from relating that to what is laid down in paragraphs 1 and 3 , it surely serves no purpose.

The UK is critical of the subcommission's advice that there was no point trying to convince it on geological grounds to disregard the morphological foot of slope of Ascension Island. ${ }^{39}$ Yet, since the UK's own case was that the island is an integral part of the Mid-Atlantic Ridge, a proposition with which it cannot say the subcommission disagreed, that is an unconvincing basis on which to seek geological evidence to the contrary. Resort to a test of appurtenance grounded in paragraph 1 rather than paragraph 4 of Article 76 is self-defeating, however, because even if this more substantial kind of test advanced by the UK applies, it would have to be a threshold issue calling into question whether a state actually has the entitlement to a continental shelf extending beyond $200 \mathrm{~nm}$ that, going on a purely geomorphological basis, it would appear to have. Instead, the UK has attempted to use the test to persuade the CLCS of the geological continuity of the Mid-Atlantic Ridge with Ascension Island to support its originally submitted foot-of-slope points, even though the CLCS at no point denied that continuity when justifying its recommendation. It merely denied that it had the effect the UK maintained it should.

The UK is on stronger ground in attacking the assumption that paragraph 3 of Article 76 makes it necessary to identify a shelf, slope and rise, ruling out volcanic islands that may have only a slope. ${ }^{40}$ However, once more it is not evident whether the subcommission actually used this as a reason for denying to Ascension Island a continental shelf beyond $200 \mathrm{~nm}$. Even if the island lacks both shelf and rise, the Commission might perfectly properly (if not necessarily correctly, in the view of other experts in geology or geophysics) conclude as it did on geomorphological grounds, having regard to where the base of the slope is at which its foot is to be sought, that the latter is located at a point where the application of subparagraph 4(a) does not produce an outer limit over $200 \mathrm{~nm}$ from the baseline. ${ }^{41}$

\footnotetext{
${ }^{39}$ UK Paper, above n 3, 6 (para 26).

${ }^{40}$ Ibid, para 28.

${ }^{41}$ Ascension Island Recommendations, above n 1, 12 (para 44).
} 


\section{Subsequent developments: the Bay of Bengal case}

A year after the UK Paper, the 2012 judgment of ITLOS in the Bay of Bengal case $^{42}$ confirmed that the relationship between paragraphs 1 and 4 of Article 76 is such that natural prolongation does not have to be demonstrated independently, i.e. on a geological basis. Rather, it is both necessary and sufficient to identify the outer edge of the continental margin as per paragraph 4, predominantly a geomorphological matter. In this case, Bangladesh had argued that the seabed in the area to be delimited consisted of sediments carried down from the Asian continent by the Ganges and Brahmaputra Rivers whose combined delta lies in Bangladesh's territory, and was thus closely connected to that territory. Bangladesh further argued that the natural prolongation of Myanmar (and of the easternmost part of Bangladesh's own territory lying east of the relevant tectonic fault line) extended no more than $50 \mathrm{~nm}$ offshore, so that, while Myanmar was still automatically entitled to $200 \mathrm{~nm}$ of continental shelf, it did not fulfil the requirements for its shelf to extend beyond that minimum guaranteed to it by paragraph 1.

A substantial majority of ITLOS held, however, that the notion of natural prolongation had been subsumed into the idea that the continental shelf is defined by the outer edge of the margin. Since in the Bay of Bengal that occurred beyond $200 \mathrm{~nm}$ from its coast, Myanmar was entitled to more than $200 \mathrm{~nm}$ of continental shelf notwithstanding the geological discontinuity relatively close to its coast on which Bangladesh had sought to rely. The relevant paragraphs of the judgment begin by stating that the notions of natural prolongation and of continental margin are 'closely interrelated' and 'refer to the same area', so that it was 'difficult to accept that natural prolongation referred to in article 76, paragraph 1 , constitutes a separate and independent criterion a coastal state must satisfy in order to be entitled to a continental shelf beyond $200 \mathrm{~nm}^{\text {, }}{ }^{43}$ Quoting only paragraph 2.2.8 of the CLCS Scientific and Technical Guidelines, ${ }^{44}$ which as noted above in reducing the test of appurtenance to a restatement of paragraph 4 of Article 76 is not necessarily representative of the preceding paragraphs, the conclusion becomes inevitable:

437. For these reasons, the Tribunal is of the view that the reference to natural prolongation in article 76, paragraph 1, of the Convention,

\footnotetext{
${ }^{42}$ Bay of Bengal, above $\mathrm{n} 14$.

${ }^{43}$ Ibid, paras 434-5.

${ }^{44}$ Ibid, para 436.
} 
should be understood in light of the subsequent provisions of the article defining the continental shelf and the continental margin. Entitlement to a continental shelf beyond $200 \mathrm{~nm}$ should thus be determined by reference to the outer edge of the continental margin, to be ascertained in accordance with article 76, paragraph 4 . To interpret otherwise is warranted neither by the text of article 76 nor by its object and purpose. ${ }^{45}$

Only Judge Gao dissented on this point. ${ }^{46}$ Judge Lucky similarly criticised the majority judgment for all but ignoring the geological evidence adduced by Bangladesh, but would have used it to justify the majority judgment's departure from an equidistance line in Bangladesh's favour, not to deny altogether any entitlement of Myanmar to a continental shelf beyond $200 \mathrm{~nm} .^{47}$

\section{Does the UK have any procedural grounds for complaint?}

If the UK wishes to pursue the matter of a continental shelf beyond $200 \mathrm{~nm}$ for Ascension Island, its options are quite limited, all the more so now in the light of the Bay of Bengal judgment. Article 8 of Annex II allows states that disagree with the recommendations received to make a 'revised or new submission', but this assumes that the new arguments would be of a scientific rather than legal character and would not ordinarily seem to be a fruitful avenue to achieve a reconsideration, although the major change in the Commission's personnel in 2012 may, exceptionally, make it worth trying. ${ }^{48}$

What would happen if instead the UK were to enact the outer limit originally submitted in its own legislation and attempt to exercise landward of this line against all comers the continental shelf sovereign rights provided for in UNCLOS Article 77? Under paragraph 8 of Article 76, such an outer limit is 'final and binding' on other states if based on the recommendation of the Commission.

\footnotetext{
45 Ibid, para 437.

${ }^{46}$ Ibid, paras 83-91 (Judge Gao, sep op).

${ }^{47}$ Ibid, passim (Judge Lucky, diss).

${ }^{48}$ Only ten of the 21 members elected in that year served on the Commission in its previous quinquennium, of whom one was first elected only ten months earlier to complete his deceased predecessor's term: see <http://www.un.org/depts/los/clcs_new/commission_membe rs.htm\#Members> and <http://www.un.org/depts/los/clcs_new/commission_members.htm\# Members_1997_2012.htm> [accessed 2 January 2013].
} 
Although in this case it obviously would not be, that does not automatically invalidate it. Unless one reads the statement of ITLOS in the Bay of Bengal case as making recommendations not just procedurally but also substantively a condition precedent to that outcome, which places rather more weight on it than it can bear, opposability of the limit to other states would continue to depend on the well-known passage from the Anglo-Norwegian Fisheries case:

The delimitation of sea areas has always an international aspect; it cannot be dependent merely upon the will of the coastal State as expressed in its municipal law. Although it is true that the act of delimitation is necessarily a unilateral act, because only the coastal State is competent to undertake it, the validity of the delimitation with regard to other States depends upon international law. ${ }^{49}$

The UK's outer limit enacted in the face of the contrary recommendation would accordingly be open to challenge under the Part XV dispute settlement procedures by any other party to UNCLOS. ${ }^{50}$ The prolonged absence of any such challenge, however, would tend to consolidate the limit over time as evidence of other states' acquiescence to the UK's exercise of continental shelf rights landward of it. ${ }^{51}$

Thus all that is left to the UK is to try to minimise the risk of other states challenging an outer limit beyond $200 \mathrm{~nm}$ by discrediting the recommendations on procedural grounds. For the reasons already given, there is little mileage in arguments that the Commission misunderstood the law, unless the UK can produce better evidence of this. It would need to show that, despite engaging the UK in a scientific debate about where the foot of slope is located, to see whether the potential for Ascension Island to generate a continental shelf beyond $200 \mathrm{~nm}$ was fulfilled, the train of thought of the subcommission or full Commission was tainted by a profoundly mistaken belief that for legal reasons Ascension Island could never have such an entitlement. Possibly the UK succeeded in persuading the subcommission of the error of its ways on that threshold issue, but felt it necessary to repeat the message in its presentation to the full Commission for

\footnotetext{
${ }^{49}$ Fisheries Case (United Kingdom v Norway), ICJ Reports 1951 p 116, 132.

${ }^{50}$ See A O Adede, The System for Settlement of Disputes Under the United Nations Convention on the Law of the Sea (1987); N Klein, Dispute Settlement in the UN Convention on the Law of the Sea (2005); J G Merrills, International Dispute Settlement $\left(5^{\text {th }}\right.$ edn, 2011) ch 8.

51 See in this regard the decision on the merits in the Temple of Preah Vihear (Cambodia $v$ Thailand), ICJ Reports 1962 p 6, 23.
} 
fear that it might revert to the erroneous approach. That is perhaps the most natural inference to draw from the UK Paper, but inference is all it is.

Should its thinking now centre on such procedural failings, the UK would have cause to regret that UNCLOS does not give the Commission legal personality, an omission that makes it much harder to apply to it even the fairly primitive framework of international administrative law (which moreover has to date been concerned much more with international organisations' relations with their staff and contractors than their relations with the states they serve). The leading textbook devotes only half a page to the Commission, and even that does no more than restate what UNCLOS says. ${ }^{52}$ But perhaps the UK could argue that most modern national legal systems have at least a basic concept of administrative law encompassing well understood principles such as due process and that, in the absence of any treaty or customary international law, it is legitimate to draw on the elements common to national systems fitting within the third source of international law identified in the Statute of the International Court of Justice: 'general principles of law recognized by civilized nations. ${ }^{53}$ At the national level, there is no shortage of decisions being overturned because of flaws in the way they were reached; typical scenarios to which the Ascension Island situation could conceivably be assimilated include taking into account an irrelevant consideration (here, the idea that islands on mid-oceanic ridges cannot have continental shelves of more than $200 \mathrm{~nm}$ ) or not approaching the question with an open mind, i.e. working from the desired conclusion to the reason supporting it rather than the other way round.

There is no avenue in international law for actually overturning the Commission's recommendation, but something like this could conceivably be used by the UK as a defence if another state challenges an Ascension Island outer limit enacted in defiance of it. On irrelevant considerations, the UK paper hints that the subcommission may have been rushing headlong towards this initially, but without the full written record we cannot know whether it got all the way. As for working backwards, there would need to be something in that record showing that either the subcommission or the full Commission was so reluctant to revisit the initial conclusion of no entitlement beyond $200 \mathrm{~nm}$, reached on an impermissible ground, that it thereafter confined itself to looking for another more acceptable ground to support it rather than restarting its reasoning de novo without preconceptions, which might have led it to a different result. But in all likelihood there is

\footnotetext{
${ }^{52}$ P Sands and P Klein, Bowett's Law of International Institutions (6 ${ }^{\text {th }}$ edn, 2009) 139.

${ }^{53}$ Statute of the International Court of Justice, Art 38(1)(c).
} 
no such 'smoking gun' to be found there, since if there were, the UK would have had nothing to gain by omitting it from its paper.

\section{Interpretation revisited}

The UK Paper ends with an invitation to other states to join the debate on the issues raised, ${ }^{54}$ but none has seen fit to take it up. ${ }^{55}$ Like the parties to any treaty, the states parties acting in concert can if they wish adopt a uniform interpretation of a given provision of UNCLOS-or, on technical questions, a uniform policy-but they have not done this. If the UK can persuade its fellow states parties of the correctness of its 'interpretation' in one of their annual meetings - a tall order now that ITLOS has endorsed a different approach-it would be hard for the Commission to insist on its contrary view. ${ }^{56}$ To do that, however, it would first need to abandon its own insistence that these meetings cannot discuss matters of substance. There has been a rather absurd debate year after year in the annual meeting of the states parties in which attempts to put matters of substance such as this on the agenda have been resisted by many states, including the $\mathrm{UK},{ }^{57}$ on the basis that the only business of such meetings is to elect periodically the members of the Commission and ITLOS and deal with associated financial and administrative matters. ${ }^{58}$ Behind such opposition is many states'

\footnotetext{
${ }^{54}$ UK Paper, above n 3, 7 (para 34).

${ }^{55}$ Information kindly supplied by Mr C Whomersley, Deputy Legal Adviser, Foreign and Commonwealth Office, in November 2012.

${ }^{56}$ As noted, though, this is less a disagreement about the meaning of 'deep ocean floor' and 'natural prolongation' than one over how the Commission's broad conception of these terms informed its approach to the UK submission; it is not obvious what precise questions the UK might formulate for the states parties as to the meaning of these terms, the desired answer to which would dictate that only its view, not the Commission's, can be the correct one.

${ }^{57}$ Likewise confirmed by Mr Whomersley.

${ }^{58}$ See (to take only the four since the 2010 recommendations) Report of the twenty-third Meeting of States Parties, UN Doc SPLOS/263, 8 July 2013, 16 (para 93); Report of the twenty-second Meeting of States Parties, UN Doc SPLOS/251, 11 July 2012, 18 (paras 98-9); Report of the twenty-first Meeting of States Parties, UN Doc SPLOS/231, 29 June 2011, 18-9 (paras 119-20); Report of the twentieth Meeting of States Parties, UN Doc SPLOS/218, 13 July 2010, 18 (para 112). These are in essentially identical terms except that the most recent ones omit the observation that the states parties have made decisions on substance in the past, notably on the implementation of the 10-year rule in UNCLOS Annex II, Art 4. The question was first discussed in 1997: see T Treves, "The General Assembly and the Meeting of States Parties in the Implementation of the LOS Convention', in A G Oude Elferink (ed), Stability and Change in the Law of the Sea: The Role of the LOS Convention (2005) 55, 62.
} 
fear that a more broad-ranging remit might lead to a Fourth United Nations Conference on the Law of the Sea and reopen matters settled by UNCLOS. ${ }^{59}$ Although that would indeed be a destabilising outcome that it is sensible to try to avoid, that goal does not require suppression of all substantive discussion. Pleasing though it would be to see such a development in the UK's thinking, other states parties for their part may be less impressed with a change of position driven by a belated realisation that the old one stands in the way of the UK pursuing, albeit legitimately, an issue of its own narrow shelf-maximising interest.

\section{Conclusion}

The most probable outcome is that the UK will simply elect to live with the Commission's recommendation with respect to Ascension Island. The lack of any sign of follow-up action to the January 2011 Note suggests that this is indeed what has happened, and if so it would be no bad result. But if it does still think UNCLOS Article 76 entitles it to a continental shelf of more than 200 $\mathrm{nm}$ there, that is likely to be because of something that happened during the subcommission's scrutiny of its submission. If it is to convince other states that it was a victim of bad process or interpretation and dissuade them from challenging its assertions of sovereign rights despite the negative recommendation, coy hints of procedural irregularity potentially undermining its legitimacy are unlikely to be enough. The UK's best course may be to make public the full record of its correspondence with the Commission and subcommission to show that its grievance is soundly based. The choice whether to do so is one that is solely in the submitting state's hands and it need not seek the Commission's consent; the Irish precedent ${ }^{60}$ is also helpful in this regard. Given the past criticisms of the opaque nature of dealings with the Commission, ${ }^{61}$ reinforcement of that precedent would be welcome in its own right even if it does not advance the UK's cause-although, if that is the case, there is no reason to expect such action. The alternative course, or one that could be pursued in parallel, is to bring the matter to the attention of the states parties for a collective view on the matter. ${ }^{62}$ These would both be

\footnotetext{
${ }^{59}$ Treves, above $\mathrm{n} 58,57$ and 61.

${ }^{60}$ Above $\mathrm{n} 7$.

${ }^{61} \mathrm{R}$ MacNab, 'The Case for Transparency in the Delimitation of the Outer Continental Shelf in Accordance with UNCLOS Article 76' (2004) 35 Ocean Development \& International Law 1, especially $12-3$.

${ }^{62}$ It is not clear whether the UK has done so; the report of the 2012 meeting cryptically indicates (Report of the twenty-second Meeting of States Parties, UN Doc SPLOS/251, 11 July 2012, para
} 
positive steps for the health of the wider system, but it is not easy to imagine the UK being prepared to do either, especially in the absence of any guarantee of success in either getting the Commission to change its mind or persuading the states parties that it is wrong.

72) that:

some delegations noted that the mandate of the Commission was limited to applying article 76 and annex II of the Convention. The mandate did not extend to matters of interpretation of the provisions contained therein. Also, it was pointed out that the Commission should enumerate the issues that it faced in the consideration of submissions and present them to the Meeting of States Parties for it to determine whether those issues were of a legal or technical nature. 